\title{
Васюкова И.Ф., Васильев А.М. \\ Несообщение о преступлении (ст. 205.6 УК РФ): проблемы квалификации и пути выхода из них
}

ФГБОУ ВО Кубанский государственный университет (Россия, Краснодар)

doi: $10.18411 / l j-02-2021-200$

idsp: ljournal-02-2021-200

\section{Аннотация}

Статья 205.6 УК РФ является нововведением в законодательстве, поэтому в настоящее время не существует единого квалификационного понимания ее применения среди сотрудников правоохранительных органов. На практике порядок применения данного уголовного производства еще не установлен в тех пределах, которые бы позволили беспрепятственно инкриминировать существующую норму. Поэтому мы постарались уделить этой норме пристальное внимание и раскрыть проблемные вопросы.

Ключевые слова: терроризм; внешняя политика; экономический рост; уголовная ответственность; уголовная ответственность.

\section{Abstract}

Article 205.6 of the Criminal Code of the Russian Federation is an innovation in legislation, so at present there is no single qualification understanding of its application among law enforcement officers. In practice, the procedure for the application of this criminal procedure has not yet been established to the extent that would allow the existing norm to be incriminated without hindrance. Therefore, we have tried to pay close attention to this norm and reveal problematic issues.

Keywords: terrorism; foreign policy; economic growth; criminal responsibility; criminal responsibility.

На наш взгляд, решение проблемы эффективной борьбы с терроризмом - одна из важных задач государства. Целесообразно ввести в систему национального законодательства введение уголовной ответственности за непредставление информации о готовящемся или совершенном террористическом акте, содействие в террористической деятельности, подготовку к террористической деятельности, организацию террористического сообщества и / или его участие в террористической деятельности. Это.

Считаем, что экономический рост в России, который наблюдается в течение последних 15 лет, повысил качество жизни граждан, сформировал стабильную политическую систему и, как следствие, способствовал проведению независимой внешней политики страны. Значительные успехи России на международной арене, присоединение Республики Крым к Российской Федерации и политические успехи в Сирии привели к более широкому использованию террористических инструментов странами, заинтересованными в политической нестабильности в России.

Согласно официальной статистике, только в 2017 году в России было совершено 1793 террористических преступления. Принимая во внимание вышеизложенное, а также угрозу, исходящую от государства, а также тот факт, что уголовная ответственность за несообщение о преступлении исключена и давно отсутствует во внутреннем Уголовном кодексе, законодатель пришел к выводу, что это необходимо возродить эту правовую категорию с учетом особенностей действующих правил.

М.И. Ковалев справедливо заметил, что «Уголовный кодекс должен постоянно меняться, переоценивать отдельные институты и правила. Все эти изменения и 
переоценки являются результатом некоторых изменений в политике уголовного права, поскольку они наводят мост между более стабильной и консервативной теорией уголовного правосудия и меняющимися реальностями жизни " [1. С. 77-82].

В научном сообществе всегда существовало два противоположных взгляда на институт отказа от недоносительства. Так, В. Н. Кудрявцев и В. Е. Эминов подчеркнули, что «декриминализация необходима, если уголовный кодекс противоречит общественной морали. Учитывая это, Уголовный кодекс 1996 года не содержал статьи о преступной халатности: «человек был застрахован от серьезного выбора: привести любимого человека или промолчать, следуя « голосу совести »»» [2. С. 78-85]. Но в то же время более ста лет назад Н.С. Таганцев отмечал: «В современных условиях государственной жизни не обязательно привлекать всех граждан к преследованию преступников.

Исходя из полученной информации, терроризм как социально-политическое явление за последние 20-30 лет стал одним из наиболее эффективных инструментов подрыва общественных и государственных институтов, влияющих на решения государственных органов и средством политической борьбы, в том числе на международном уровне. В СМИ все чаще высказываются мнения о централизованном управлении террористическими операциями и финансировании террористических организаций развитыми странами, которые заинтересованы в подрыве конституционного строя, существующего в отдельных государствах, с целью заставить субъектов международных отношений принимать важные дипломатические решения.

Мы считаем, что сообщение о серьезном или особо серьезном преступлении должно быть общественной обязанностью всех людей и всех граждан. Юридическая обязанность сообщать о соответствующих нарушениях должна проистекать из уголовного права, устанавливающего ответственность за неисполнение преступления.

Федеральным законом от 6 июля 2016 г. № 375-Ф3 «О внесении изменений в Уголовный кодекс Российской Федерации и Уголовно-процессуальный кодекс Российской Федерации в части установления дополнительных мер по борьбе с терроризмом и общественной безопасности», добавлена новая статья. Добавлен в УК РФ ст. 205.6, в которой имеются признаки состава преступления - не сообщения о преступлении.

Следует отметить, что институт непредоставления информации хорошо известен российской системе уголовного права. Таким образом, согласно исходной редакции Уголовного кодекса РСФСР в 1960 году, лицо подлежало уголовной ответственности в случае непредставления сообщения о готовящемся или совершенном достоверно известном преступлении. Статья 190 Уголовного кодекса РСФСР содержала 19 преступлений, о которых не сообщалось, за которые предусмотрена уголовная ответственность. Примеры включают такие комбинации, как измена, шпионаж, теракт и другие. Позже Указом Президиума Верховного Совета РСФСР от 30 марта 1988 г. этот список был расширен до 25 преступлений.

С введением в действие статьи 205.6 Уголовного кодекса Российской Федерации отказ от сообщения властям, уполномоченным расследовать сообщения о преступлениях с участием лица (лиц), действительно знающего информацию, готовящего, совершающего или совершенного по крайней мере одно из предусмотренных правонарушения, указанные в этой статье, уголовно наказуемы по ст.ст. 205, 205.1, 205.2, 205.3, 205.4, 205.5, 206, 208, 211, 220, 221, 277, 278, 279, 360 и 361 УК РФ. Вы сразу заметите несоответствие заголовка статьи содержанию актов, указанных в положении. Несообщение о преступлении влечет за собой не сообщение о преступлении, а не одно или несколько лиц, как указано в положении статьи 205.6 Уголовного кодекса Российской Федерации, по которой оно готовится. Кроме того, непредставление сообщения о преступлении также включает непредставление сообщения о лице, готовившем его. Таким образом, название статьи 205.6 УК РФ шире, 
чем содержание ее положения, поскольку само название статьи «впитывает» невозможность связаться с лицом, которое готовит, совершает или совершает хотя бы одно из предвиденные правонарушения [3. С. 137-141].

Исходя из имеющихся статистических данных мы можем сделать умозаключение о росте числа преступлений террористического характера. На наш взгляд, это говорит о том, что меры, ориентированные на противодействие данному общественно опасному явлению, являются малоэффективными. У нас возникает также вопрос об эффективности мер уголовно-правового характера, которые сводятся к нулю при совершении взрывов террористами-смертниками. Не стоит ли обращаться к специальной литературе, чтобы понять, что противодействие таким атакам является чрезмерно затруднительным. Смертник всегда может пройти туда, куда сможет попасть любой человек. Особенно по нашему мнению не защищены объекты транспортной инфраструктуры - аэропорты, автовокзалы, железнодорожные вокзалы, метро и др.

Объективная сторона ст. 205.6 УК РФ является пассивное поведении лица, то есть то, что деяние выражается в форме бездействия. [4. С. 187-195] активное поведение исчезает. Исполнитель оказывает содействие в сокрытии лиц, причастных к преступлению, фактически является соучастником (если заранее дано обещание оказать такое содействие) или совершает предварительное сокрытие преступления (статья 316 УК РФ). Непредставление сообщения о преступлении должно рассматриваться как преступное упущение с точки зрения возможности. Учитывая такую возможность, я думаю, что мы должны приступить к определению истинной способности людей не только понимать характер известных фактов о готовящемся или совершаемом террористическом преступлении конкретным лицом, но и иметь реальную возможность информировать органы власти о сообщениях о преступлениях.

На наш взгляд, ситуация еще более осложняется, когда преступление совершает член семьи, родственник или другое лицо, близкое для субъекта недонесения лицом. И здесь при выборе между гражданским долгом и личными чувствами лица, совершившего преступление, часто возникает конфликт мотивов, который иногда превращается в настоящую личную трагедию. Создание таких человеческих трагедий мало способствует укреплению авторитета правосудия. Что касается обеспечения эффективной деятельности правоохранительных органов в борьбе с преступностью, то я думаю, что при подготовке кадров и научно-техническом вооружении они обладают наглядным арсеналом средств и могут справиться, не заставляя граждан сообщать о совершенных преступлениях [5. С. 761-766].

Следует отметить, что уголовная ответственность должна быть дискредитирована в том случае, если подозреваемому не сообщается достоверно известных сведений о лице по объективным причинам, например, ночью, временная нетрудоспособность, исключая возможность общения, беспомощное состояние, отсутствие тех или иных технических средств связи (телефон, телефонная служба, доступ к глобальной сети Интернет или ограниченный оператором доступ к услугам связи).

Отсутствие сроков не позволяет в полной мере квалифицировать деяние, поскольку не существует условий, присущих уголовной ответственности, что вынуждает автора прибегать к аналогиям. Однако в соответствии с п."а" ч. 1 ст. 78 УК РФ никто не может быть привлечен к уголовной ответственности за непредставление сведений о преступлении, о котором стало известно более двух лет назад.

В процессе применения статьи 205.6 УК РФ может возникнуть еще один вопрос: какие органы уполномочены рассматривать сообщения о преступлениях? Некоторые сотрудники правоохранительных органов считают, что их перечень содержится в ст. 150, 151 Уголовно-процессуального кодекса, но в этих статьях не упоминаются такие правоохранительные структуры, как суды, органы прокуратуры, Федеральная служба 
войск нацгвардии. Разве органы, уполномоченные получать заявки, не являются федеральными органами исполнительной власти?

Статья 205.6 УК РФ предполагает наличие прямого умысла, так как лицо понимает, что имеет сведения о преступнике, совершившем деяния, перечисленные в ст. 205.6 УК РФ, и желает скрыть эту информацию путем ее несообщения. Более того, понимание и осознание своего поведения при достоверном знании скрытой информации свидетельствует о желании действовать определенным образом, с волевым отношением к ней как к нужной, а не безразличной. В этой связи я хотела бы сделать критическое замечание относительно определения преступника.

В настоящее время практика применения ст. 205.6 УК РФ практически отсутствует. Так, 6 февраля 2017 г. Кировский районный суд города Астрахани вынес первый в России приговор местному жителю Г.У., признав его виновным в совершении преступления, предусмотренного ст. 205.6 УК РФ, виновный был приговорен к штрафу в 70 тысяч рублей. В ходе следствия было установлено, что Г.У., обладал достоверной информацией о том, что его знакомый, гражданин Кыргызстана А.Р., участвовал в вооруженном незаконном формировании [6. С. 58-61].

Итак, подведем итоги. В связи с вышеизложенным считаем разумным установить в Федеральном законе «О противодействии терроризму» для граждан, иностранных граждан и лиц без гражданства обязанность сообщать о готовящемся или совершенном террористическом акте, поощрять террористическую деятельность, подготовку к осуществлению террористической деятельности, организацию, а также в УК РФ предлагаю ввести норму об ответственности за неявку о готовящемся или совершенном террористическом акте., Содействие террористической деятельности, подготовка кадров для осуществления террористической деятельности, организации террористического сообщества и / или его участие.

$$
* * *
$$

1. Зубарева К.В., Бадуртдинов А.А., Васильев А.М. Домашнее насилие, выраженное в побоях, избиении и в угрозе убийством // В сборнике: Фундаментальная и прикладная наука: состояние и тенденции развития. Сборник статей V Международной научно-практической конференции. 2020. C. $77-82$.

2. Скоян С.М., Васильев А.М. Противоречия и необходимость в квалификации нормы СТ. 207.1 УК РФ // Право и образование. 2020. № 8. С. 78-85.

3. Зубарева К.В., Бадуртдинов А.А., Васильев А.М. Насилие в семье как основной показатель при квалификации // Международный научно-исследовательский журнал. 2020. № 6-4 (96). С. 137-141.

4. Sidorova E.Z., Tarubarov V.V., Okruzhko V.Y., Vasiliev A.M., Pelevin S.I. Safety issues of the russian educational system // Journal of Advanced Research in Law and Economics. 2020. T. 11. № 1. C. 187195.

5. Pelevin S., Vasiliev A., Taubaev B., Tileubergenov Y. The participation of youth of western countries in political life of the society. the youth in the political life of the society // Journal of Advanced Research in Law and Economics. 2018. T. 9. № 2 (32). C. 761-766.

6. Васильев А.М., Окружко В.Ю. Особенности криминологической характеристики личности террориста // Юридическая наука. 2019. № 9. С. 58-61.

\section{Дудоров Т.Д., Кирюхин А.Ю. \\ Понятие «уголовно-процессуальная функция» в науке уголовного процесса: ретроспективный анализ \\ ФГБОУВО Российский государственный университет правосудия} (Россия, Воронеж)

doi: $10.18411 / l j-02-2021-201$

idsp: ljournal-02-2021-201

\section{Аннотация}

В статье предлагается анализ становления и развития учения об уголовнопроцессуальных функциях в науке российского уголовного процесса, делается вывод о 